\title{
Simultaneous optical label erasure and insertion in a single wavelength conversion stage of combined FSK/IM modulated signals
}

\author{
Citation for published version (APA): \\ Vegas Olmos, J. J., Zhang, J., Van Holm-Nielsen, P., Tafur Monroy, I., Polo, V., Koonen, A. M. J., Peucheret, C., \\ \& Prat, J. (2004). Simultaneous optical label erasure and insertion in a single wavelength conversion stage of \\ combined FSK/IM modulated signals. IEEE Photonics Technology Letters, 16(9), 2144-2146. \\ https://doi.org/10.1109/LPT.2004.833084
}

DOI:

10.1109/LPT.2004.833084

Document status and date:

Published: 01/01/2004

Document Version:

Publisher's PDF, also known as Version of Record (includes final page, issue and volume numbers)

\section{Please check the document version of this publication:}

- A submitted manuscript is the version of the article upon submission and before peer-review. There can be important differences between the submitted version and the official published version of record. People interested in the research are advised to contact the author for the final version of the publication, or visit the DOI to the publisher's website.

- The final author version and the galley proof are versions of the publication after peer review.

- The final published version features the final layout of the paper including the volume, issue and page numbers.

Link to publication

\footnotetext{
General rights

- You may freely distribute the URL identifying the publication in the public portal. follow below link for the End User Agreement:

www.tue.nl/taverne

\section{Take down policy}

If you believe that this document breaches copyright please contact us at:

openaccess@tue.nl

providing details and we will investigate your claim.
}

Copyright and moral rights for the publications made accessible in the public portal are retained by the authors and/or other copyright owners and it is a condition of accessing publications that users recognise and abide by the legal requirements associated with these rights.

- Users may download and print one copy of any publication from the public portal for the purpose of private study or research.

- You may not further distribute the material or use it for any profit-making activity or commercial gain

If the publication is distributed under the terms of Article $25 \mathrm{fa}$ of the Dutch Copyright Act, indicated by the "Taverne" license above, please 


\title{
Simultaneous Optical Label Erasure and Insertion in a Single Wavelength Conversion Stage of Combined FSK/IM Modulated Signals
}

\author{
J. J. Vegas Olmos, J. Zhang, P. V. Holm-Nielsen, I. Tafur Monroy, V. Polo, A. M. J. Koonen, C. Peucheret, and J. Prat
}

\begin{abstract}
We report on optical label swapping of combined frequency-shift keying/intensity modulation (FSK/IM) modulated signals by using a single wavelength conversion stage based on a semiconductor optical amplifier Mach-Zehnder interferometer. Simultaneous FSK label erasure and insertion at a bit rate of $156 \mathrm{Mb} / \mathrm{s}$ is successfully achieved for a $10-\mathrm{Gb} / \mathrm{s}$ IM payload with transmission over two spans of 40-km standard single-mode fiber.
\end{abstract}

Index Terms-Optical burst switching, optical communication, wavelength conversion, wavelength-division-multiplexing networks.

\section{INTRODUCTION}

$\mathbf{O}$ PTICAL label swapping (OLS) is a technique that enables the implementation of packet routing and forwarding functions in IP over wavelength-division multiplexing [1]. OLS supports high bit rates for payload data transmission while employing low-speed electronics in the core nodes for label processing. Several approaches have been studied for labeling optical packets [2], among those the combined frequency-shift keying/intensity modulation (FSK/IM) is one of the promising methods due to its in-band characteristics and simplicity of implementation [3].

In this letter, we demonstrate for the first time simultaneous FSK optical label insertion, erasure, and swapping based on a single semiconductor optical amplifier Mach-Zehnder interferometer (SOA-MZI) wavelength conversion stage in combination with the use of a grating-assisted coupler sampled reflector (GCSR) tuneable laser [4] as FSK signal source.

We also present an experimental assessment of some of the key functionalities of a core router (label erasure, insertion of a new label, and wavelength conversion), including two hops of fiber transmission.

Manuscript received January 23, 2004; revised May 25, 2004. This work was supported in part by the European Commission within the IST project Switching Technologies for Optically Labeled Signals (STOLAS).

J. J. Vegas Olmos, I. Tafur Monroy, and A. M. J. Koonen are with the Faculty of Electrical Engineering, COBRA Research Institute, Eindhoven University of Technology, 5600MB Eindhoven, The Netherlands (e-mail: j.j.vegas@tue.nl; i.tafur@tue.nl; a.m.j.koonen@tue.nl).

J. Zhang, P. V. Holm-Nielsen, and C. Peucheret are with the Research Center COM, Technical University of Denmark, DK-2800 Kgs. Lyngby, Denmark (e-mail: jz@com.dtu.dk; vhn@com.dtu.dk; cp@com.dtu.dk).

V. Polo and J. Prat are with the GCO Optical Communications Group, Technical University of Catalonia, 08034 Barcelona, Spain (e-mail: polo@ tsc.upc.es; jprat@tsc.upc.es).

Digital Object Identifier 10.1109/LPT.2004.833084

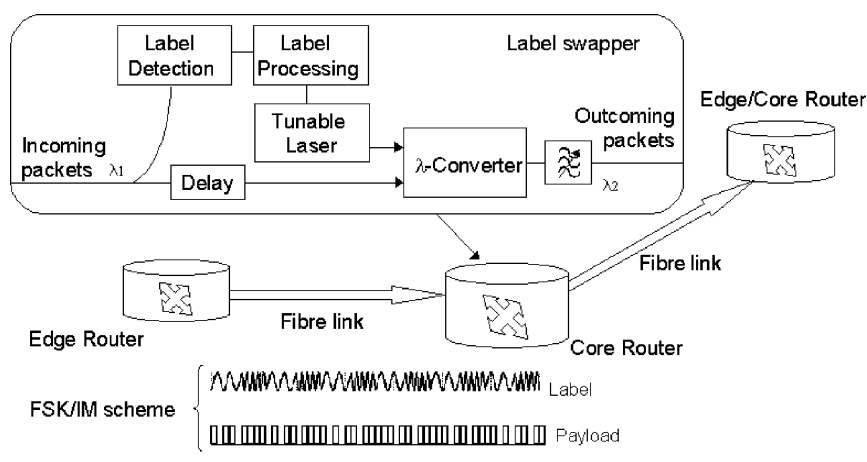

Fig. 1. Core router architecture in a combined FSK/IM modulation format scheme.

\section{Router ARChitecture of AN All-OpticAl PACKET-SWITCHED NETWORK BASED ON COMBINED FSK/IM LABELING}

At the ingress edge router of the network, the incoming packets are classified and aggregated to form a forward equivalent class. Their payload information is conveyed by modulating the intensity of the optical lightwave carrier. The label information (destination, quality of service, etc) is FSK encoded, thus obtaining a signal with a combined IM and FSK format: FSK/IM. The routing and forwarding operation at the core nodes is based on the information transported in the FSK encoded data. A global scheme of this proposed architecture is shown in Fig. 1.

To perform label swapping, a fraction of the power of the incoming optical signal is tapped and then detected for electronic label processing. As a result of this process, the router can consult a routing table, and insert the new label to be attached to the IM signal for next hop transmission. The remaining part of the incoming signal is then input to an SOA-MZI for wavelength conversion. A delay line is used to buffer the incoming burst of data while the label is read, processed, and the laser is tuned to the new wavelength. A complete analysis of the value of the delay is beyond the scope of the present work, as it depends on the actual implementation of the label processing circuit and on the duration of the label, itself set by network requirements. As an order of magnitude, switching of GCSR lasers over $40 \mathrm{~nm}$ has been reported with switching times less than $100 \mathrm{~ns}$ [5]. The pump signal used in the SOA-MZI wavelength converter is generated by a GCSR tunable laser that is frequency modulated with the new label information [6], [7]. Due to its agile wavelength tuneability, this device represents one of the key building blocks 


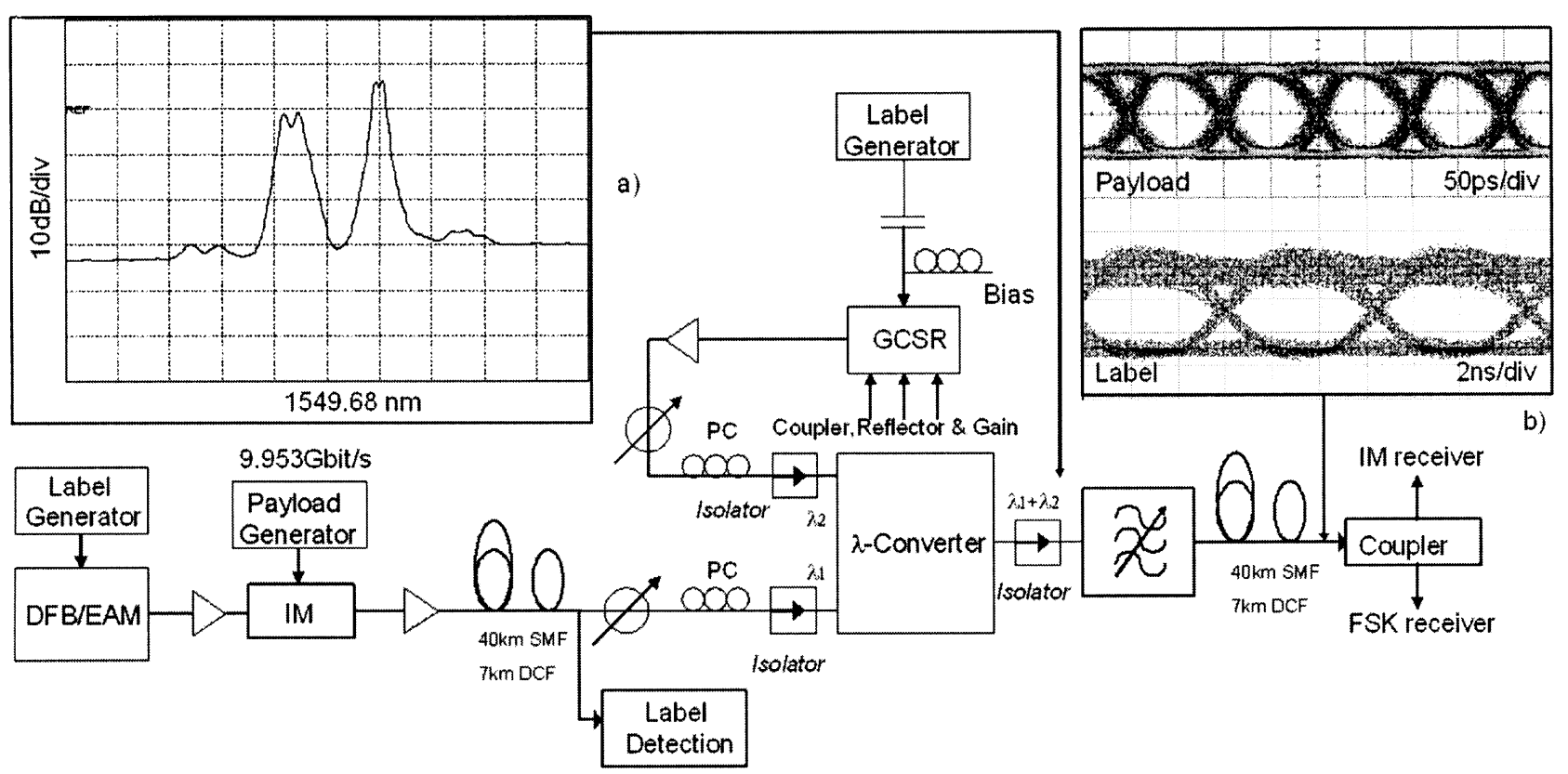

Fig. 2. Experimental setup for FSK/IM label generation, and label swapping in a single SOA-MZI wavelength converter. (a) Optical spectrum at the output of the SOA-MZI with 4-nm span (b) Eye diagrams of the 10-Gb/s IM payload (top) and the 156-Mb/s label (bottom) after label swapping and two-hop transmission.

of optical core routers in OLS networks. In the wavelength conversion process, the FSK label information encoded in the old lightwave carrier is erased, as the scheme relies on cross-phase modulation in the SOA-MZI wavelength converter. Therefore, only the IM payload information will be copied onto the output new wavelength, containing the new FSK label generated by the GCSR. In this way, after the wavelength conversion stage, the labeled packet is ready to be sent over the fiber link to the next network node. FSK sources might have different properties for different nodes of the networks, which does not matter as long as the label can be properly detected at the next node.

\section{EXPERIMENTS AND RESULTS}

The experimental setup is shown in Fig. 2. At the edge router, generation of an optical 156-Mb/s FSK modulated signal is obtained by directly modulating the electrical current of an integrated distributed feedback-electroabsorption modulator laser source emitting at $1549.32 \mathrm{~nm}$, as previously reported in [8]. The optical FSK modulated signal, with a tone spacing of $20 \mathrm{GHz}$, is then fed into an optical Mach-Zehnder intensity modulator operated at $10 \mathrm{~Gb} / \mathrm{s}$, resulting in a combined FSK/IM modulation format scheme. The extinction ratio of the IM is adjusted to $6 \mathrm{~dB}$, which is found to allow both the FSK and the IM receivers to perform at a proper receiver sensitivity. The combined FSK/IM optical signal is boosted and launched into a dispersion compensated fiber link composed of $40 \mathrm{~km}$ of standard single-mode fiber (SMF) followed by $7 \mathrm{~km}$ of dispersion-compensating fiber (DCF).

In the core router, the new FSK label signal is generated by modulating the phase current of the GCSR laser [7], whereas, $\mathrm{dc}$ currents are applied to the other sections (coupler, reflector, and gain) for tuning to a desired wavelength as well as to control the optical output power. The device used in the experiment supports 41 channels in the range of $1529.55-1561.42 \mathrm{~nm}$ with a channel spacing of $100 \mathrm{GHz}$. A frequency deviation of $10 \mathrm{GHz}$ was selected for FSK modulation of the GCSR laser, and its central wavelength was adjusted to $1550.1 \mathrm{~nm}$.

The optical spectrum at the output of the SOA-MZI wavelength converter is shown as Fig. 2, inset (a). Due to the copropagating operation of the SOA-MZI, we can observe the spectra of the new converted signal as well as the residual old signal. As the two types of laser sources used in the experiment have different frequency-modulation efficiencies, the two FSK signals have different modulation depths, hence, the different spectral widths of the signals observed in the figure. An optical bandpass filter is used to remove the original, nondesired wavelength, before launching the signal again into another $40-\mathrm{km}$-long dispersion compensated fiber link (40 km of SMF and $7 \mathrm{~km}$ of DCF). After transmission, both payload and label are detected as shown in Fig. 2, inset (b), showing clear and open eye diagrams. In the eye diagram of the FSK label, the effect of the intensity modulated signal can be observed on the "one" level as a superimposed set of intensity levels at $10 \mathrm{~Gb} / \mathrm{s}$ [lower eye diagram of Fig. 2, inset (b)].

Fig. 3 shows the measured bit-error-rate (BER) performance as a function of the average received optical power. For the IM receiver, the received optical power level yielding a BER of $10^{-9}$ was measured to be $-28 \mathrm{dBm}$. Therefore, only $0.5-\mathrm{dB}$ power penalty is measured for the IM payload after two-hop transmission including label swapping. As the label is generated by two different FSK sources, one cannot directly compare the FSK performance before and after label swapping. However, the FSK-modulated signal suffers a higher power penalty of approximately $2 \mathrm{~dB}$ due to transmission over the second span. This is attributed to imperfect dispersion compensation at this wavelength, which is critical with tone spacing as large as $10 \mathrm{GHz}$, as well as crosstalk from the IM payload due to nonlinear cou- 

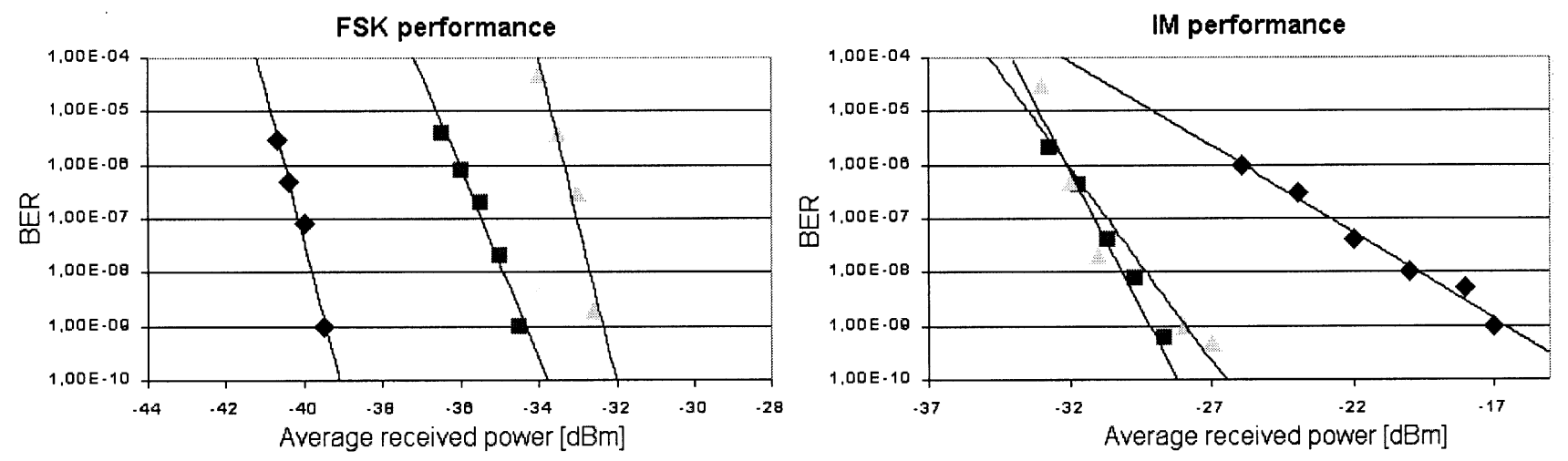

- original signal from the FSKJM source

- after 1-hop transmission including swapping

after 2-hop transmission including swapping

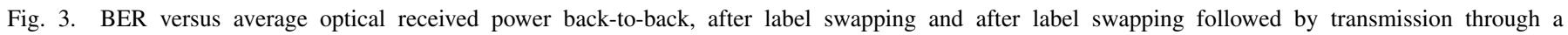
dispersion-compensated span.

pling in the fibers. For comparison, the power penalty incurred for FSK label insertion in the same MZI had been measured to be $0.5 \mathrm{~dB}$, as reported in [5].

Although the FSK performance suffers an average of 2-dB power penalty in each span, including the wavelength conversion stage, this degradation does not affect the global network performance because a new label will be reinserted at each node. The IM performance demonstrates the regeneration effect due to the interferometric behavior of the SOA-MZI wavelength converter [9]. Therefore, a high level of scalability is possible by using the combined scheme.

\section{CONCLUSION}

We have experimentally demonstrated, for the first time, some key functionalities of an optical label switching core router making use of the FSK/IM combined modulation scheme. Label erasure and insertion was simultaneously achieved in a single wavelength conversion stage for a $10-\mathrm{Gb} / \mathrm{s}$ IM payload and a 156-Mb/s FSK label. Successful transmission of the combined IM/FSK signal is reported over two hops of 40-km length, consisting each of a dispersion-compensated SMF link. These results demonstrate the potential for the realization of compact FSK/IM label-swapping devices based on integrated SOA-MZI wavelength converters, assisted by agile tunable lasers. Such a compact label-swapping module is a de- sirable key building block for future core routers in optical label switched networks.

\section{REFERENCES}

[1] C. Qiao, "Labeled optical burst switching for IP-over-WDM integration," IEEE Commun. Mag., vol. 38, pp. 104-114, Sept. 2000.

[2] I. T. Monroy, J. Zhang, N. Chi, P. V. Holm-Nielsen, C. Peucheret, A. M. J. Koonen, J. J. V. Olmos, and G. D. Khoe, "Techniques for labeling of optical signals in burst switched networks," in Proc. WOBS (+ OptiComm.) 2003, Dallas, TX, Oct. 16, 2003, pp. 1-11.

[3] K. G. Vlachos, I. T. Monroy, A. M. J. Koonen, C. Peucheret, and P. Jeppesen, "Stolas: Switching technologies for optically labeled signals," IEEE Commun. Mag., vol. 41, pp. S9-15, Nov. 2003.

[4] O. A. Lavrova and D. J. Blumenthal, "Detailed transfer matrix based dynamic model for multisection widely-tunable GCSR lasers," J. Lightwave Technol., vol. 18, pp. 1274-1283, Sept. 2000.

[5] C.-K. Chan, K. L. Sherman, and M. Zirngibl, "A fast 100-channel wavelength-tunable transmitter for optical packet switching," IEEE Photon. Technol. Lett., vol. 13, pp. 729-731, July 2003.

[6] J. J. V. Olmos, I. T. Monroy, A. M. J. Koonen, and Y. Yu, "High bit-rate combined FSK/IM modulated optical signal generation by using GCSR tunable laser sources," Opt. Express, vol. 11, no. 23, pp. 3136-3140, 2003.

[7] Y. Yu, G. Mulvihill, S. O'Duill, and R. O'Dowd, "Performance implications of wide-band lasers for FSK modulation labeling scheme," IEEE Photon. Technol. Lett., vol. 16, pp. 39-41, Jan. 2004.

[8] J. Zhang, N. Chi, P. V. Holm-Nielsen, C. Peucheret, and P. Jeppesen, "An optical FSK transmitter based on an integrated DFB laser-EA modulator and its application in optical labeling," IEEE Photon. Technol. Lett., vol. 15, pp. 984-986, July 2003.

[9] K. E. Stubkjaer, "Semiconductor optical amplifier-based all-optical gates for high-speed optical processing," IEEE J. Select. Topics Quantum Electron., vol. 6, pp. 1428-1435, Nov./Dec. 2000. 